\title{
The Covid-19 Pandemic can be stopped with Probiotics
}

\author{
Goran Belojevic* \\ Institute of Hygiene and Medical Ecology, Faculty of Medicine, University of Belgrade, Serbia \\ *Corresponding author: Goran Belojevic, Institute of Hygiene and Medical Ecology, Faculty of Medicine, University of \\ Belgrade, Serbia
}

\begin{abstract}
ARTICLE INFO
Received: 幽 December 04, 2020

Published: 蔧 January 18, 2021

Citation: Goran Belojevic. The Covid-19 Pandemic can be stopped with Probiotics. Biomed J Sci \& Tech Res 33(2)-2021. BJSTR. MS.ID.005364.

\section{ABSTRACT}

The disastrous COVID19 pandemic is bringing death, suffering, economic crisis and the instability to the world's peace. The solutions for stopping COVID19 pandemic are urgently needed. We present an alternative approach to vaccination, based on the power of nature - a mass prevention and prophylaxis of the COVID 19 with probiotics. This approach is based on the fundamental discoveries of Nobel laureate Ilja Iljić Mećnikov from 1908, as well as on the theoretical and applied scientific papers published during the pandemic: Compared to vaccination, this public health intervention may be more effective, much cheaper, with almost negligible side effects and last but not the least - it is immediately and widely applicable.
\end{abstract}

Keywords: SARS; Corona virus; Pandemic; Probiotics

\section{Introduction}

The COVID-19 is an unprecedented pandemic that is bringing blood, sweat and tears to contemporary world [1]. The vaccines are ante portas but never so fast and so risky in the history [2]. The scientific community is expected to offer alternative solutions also, if there are any? Well, there are! The miraculous commensal lactobacteria in human guts were first described by a Nobel Prize Laureate in Physiology and Medicine for 1908 - Ilya Ilyich Mechnikov, a Russian zoologist from the Pasteur Institute in Paris. Indeed, about 60 trillion commensal bacteria in human colon are a powerful natural barrier against pathogens, including all viruses [3]. Dysbiosis and diarrhea are documented signs of the COVID19 [4]. ACE2 receptors for SARS CoV-2 are identical in the lung and intestinal mucosa and gut microbiota are the guards that do not allow the coronavirus to approach these receptors [5]. The crucial feature of an efficient immune system is a balanced reaction to external and internal threats. This is of a paramount importance for preventing a cytokine storm and an acute respiratory distress syndrome in the COVID19 [6]. The prevention and prophylaxis of COVID-19 with probiotics has been proposed, based both on the biological plausibility and case reports [7-11]. Recent works related to the microbiota in cancer patients on chemotherapy and stem-cell engraftment support the importance of gut microbiota for the whole immune system and their effect on systemic immune cell dynamics [12]. If the diversity of gut microbiota is preserved it allows for a huge immunomodulatory impact and an important epigenetic system [13].

\section{A Model for Stopping the COVID-19 pandemic}

Probiotics are over-the-counter drugs with literally no side effects except for bloating and flatulence and probably the only medication that can be freely given to newborns and pregnant women. Caution is necessary only in those with chronic disabling diseases, central venous catheters, and systemic infections $[14,15]$. A mass public health preventive and prophylactic intervention may be conducted with one probiotic capsule daily with at least $10 \exp 9$ of the Lactobacillus and Bifidobacterium species, during a meal [16]. Those with at least one symptom of COVID-19 (raised temperature, weakness, and dry cough) - one capsule three times daily. Those who are on non-invasive or invasive mechanical ventilation - two capsules of probiotics three times daily via oral or enteral feeding. There is no age limit.

\section{Conclusion}

We propose a natural alternative to the vaccination solution of the COVID19 pandemic. Based on the evidence for biological 
plausibility and the positive experiences from case reports we present a model of stopping the COVID19 pandemic with probiotics.

\section{References}

1. COVID19 - Coronavirus Pandemic.

2. Mc Fee RB (2020) COVID-19: Therapeutics and interventions currently under consideration. Dis Mon 66(9): 101058.

3. Ley RE, Peterson DA, Gordon JI (2006) Ecological and Evolutionary Forces Shaping Microbial Diversity in the Human Intestine. Cell 124 837-848.

4. Velavan TP, Meyer CG (2020) The COVID-19 epidemic. Trop Med Int Health 25: 278-280.

5. Dhar D, Mohanty A (2020) Gut microbiota and Covid-19- possible link and implications. Virus Res 285: 198018.

6. He Y, Wang J, Li F, Shi Y (2020) Main clinical features of COVID19 and potential prognostic and therapeutic Value of the Microbiota in SARS CoV-2 Infections. Front Microbiol 11: 1302.

7. Belojevic G, Prasher D (2019) Music of microbiota against SARS CoV-2. Noise Health 21(100): 97.

8. Bottari B, Castellone V, Neviani E (2020) Probiotics and Covid-19. Int ] Food Sci Nutr 12: 1-7.

\section{ISSN: 2574-1241}

DOI: 10.26717/BJSTR.2021.33.005364

Goran Belojevic. Biomed J Sci \& Tech Res

(C) This work is licensed under Creative

Submission Link: https://biomedres.us/submit-manuscript.php
9. Belojevic G (2020) Microbiota Against SARS CoV-2: Case Reports and a Model for Stopping the COVID-19 Pandemic. Journal of Clinical and Medical Case Reports 1(4).

10. Akour A (2020) Probiotics and COVID-19: is there any link? Lett Appl Microbiol 71: 229-234.

11. Mak JWY, Chan FKL, Ng SC (2020) Probiotics and COVID-19: one size does not fit all. Lancet Gastroenterol Hepatol 5: 644-645.

12. Schluter J, Peled JU, Taylor BP, Markey KA, Smith M, et al. (2020) The gut microbiota is associated with immune cell dynamics in humans. Nature 588(7837): 303-307.

13. Geva Zatorsky N, Sefik E, Kua L, Pasman L, Guan Tan T, Ortiz Lopez A et al. (2017) Mining the Human Gut Microbiota for Immunomodulatory Organisms. Cell 168(5): 928-943.

14. Williams NT (2010) Probiotics. Am J Health Syst Pharm 67: 449-458.

15. Suez J, Zmora N, Segal E, Elinav E (2019) The pros, cons, and many unknowns of probiotics. Nat Med 25: 716-729.

16. Sonomoto K, Yokota A (2011) Lactic Acid Bacteria and Bifidobacterial: Current Progress in Advanced Research. Poole (UK): Caister Academic Press, UK.

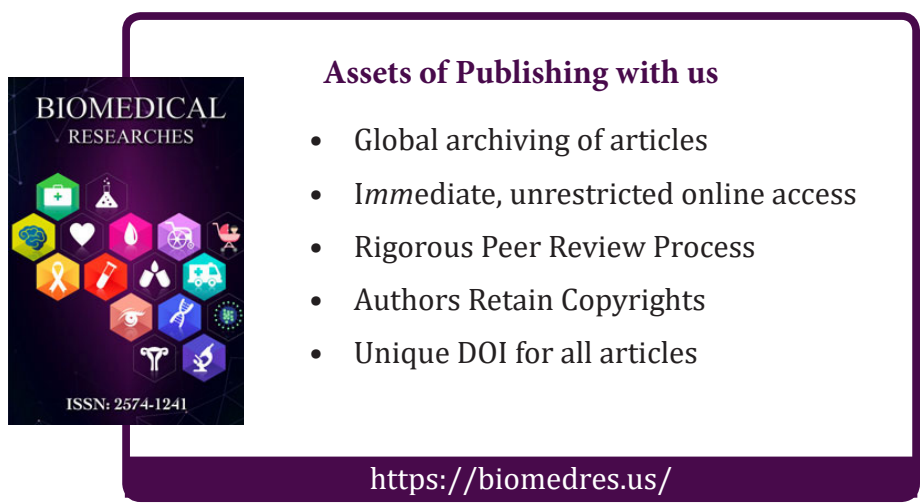

